\title{
The role of libraries in teaching doctoral students to become information-literate researchers
}

Citation for published version (APA):

Ince, S., Hoadley, C., \& Kirschner, P. A. (2019). The role of libraries in teaching doctoral students to become information-literate researchers: A review of existing practices and recommendations for the future. Information and Learning Sciences, 120(3/4), 158-172. https://doi.org/10.1108/ils-07-2018-0058

DOI:

10.1108/ils-07-2018-0058

Document status and date:

Published: 01/01/2019

Document Version:

Publisher's PDF, also known as Version of record

Document license:

Taverne

Please check the document version of this publication:

- A submitted manuscript is the version of the article upon submission and before peer-review. There can be important differences between the submitted version and the official published version of record. People interested in the research are advised to contact the author for the final version of the publication, or visit the DOI to the publisher's website.

- The final author version and the galley proof are versions of the publication after peer review.

- The final published version features the final layout of the paper including the volume, issue and page numbers.

Link to publication

\section{General rights}

Copyright and moral rights for the publications made accessible in the public portal are retained by the authors and/or other copyright owners and it is a condition of accessing publications that users recognise and abide by the legal requirements associated with these rights.

- Users may download and print one copy of any publication from the public portal for the purpose of private study or research.

- You may not further distribute the material or use it for any profit-making activity or commercial gain

- You may freely distribute the URL identifying the publication in the public portal.

If the publication is distributed under the terms of Article 25fa of the Dutch Copyright Act, indicated by the "Taverne" license above, please follow below link for the End User Agreement:

https://www.ou.nl/taverne-agreement

Take down policy

If you believe that this document breaches copyright please contact us at:

pure-support@ou.nl

providing details and we will investigate your claim.

Downloaded from https://research.ou.nl/ on date: 26 Apr. 2023 


\section{ILS}

$120,3 / 4$

\section{8}

Received 10 July 2018 Revised 12 August 2018 Accepted 13 August 2018

\section{The role of libraries in teaching doctoral students to become information-literate researchers \\ A review of existing practices and recommendations for the future}

\author{
Sharon Ince \\ Seton Hall University, South Orange, New Jersey, USA \\ Christopher Hoadley \\ New York University, New York City, New York, USA, and \\ Paul A. Kirschner \\ Open University of the Netherlands, Heerlen, The Netherlands \\ and University of Oulu, Oulu, Finland
}

\begin{abstract}
Purpose - This paper aims to review current literature pertaining to information literacy and digital literacy skills and practices within the research workflow for doctoral students and makes recommendations for how libraries (and others) can foster skill-sets for graduate student research workflows for the twenty-first century scholarly researcher.
\end{abstract}

Design/methodology/approach - A review of existing information literacy practices for doctoral students was conducted, and four key areas of knowledge were identified and discussed.

Findings - The findings validate the need for graduate students to have training in information literacy, information management, knowledge management and scholarly communication. It recommends empirical studies to be conducted to inform future practices for doctoral students.

Practical implications - This paper offers four areas of training to be considered by librarians and faculty advisers to better prepare scholars for their future.

Originality/value - This paper presents a distinctive synthesis of the types of information literacy and digital literacy skills needed by graduate students.

Keywords Digital literacy, Information literacy, Doctoral students, Graduate students, Information problem solving (IPS), Research workflows

Paper type Conceptual paper

\section{Introduction}

Over the past two decennia, the shift in information technology from stand-alone individual applications to personal and shared applications has greatly impacted researchers' workflows. "Modern information technologies have influenced all disciplines, but certain institutions: research and scholarship, librarianship and curation, publishing and media, and most of all education, have been deeply affected" (Hoadley, 2011, p. 1). Scholars are increasingly using multiple types of technology within their research workflow, for example Google Docs ${ }^{\mathrm{TM}}$, Evernote ${ }^{\circledR}$, ResearchGate ${ }^{\circledR}$ and/or Dropbox ${ }^{\mathrm{TM}}$. The availability and use of new technologies, especially those which allow the sharing of files and/or the ability of 
multiple persons to simultaneously work on them is an increasingly important factor in the scholarly research and communications process. This has become apparent in the doctoral student research workflows as well, especially in the research-intensive phase of doctoral study. As noted in a recent study by Nicholas et al. (2017, p. 157), "the 'new wave' of researchers, born digital or long conditioned by living in a digital environment, early career researchers (ECRs) constitute the breeding ground for tomorrow's established researchers." Numerous postgraduate student blogs help illustrate the digitally enabled practices of early career scholars. These blogs help share tips and skills outside of formal postgraduate training (see Kathryn Ringland's "Grad Student Workflow, Part 1" at http://kateringland. com/grad-student-workflow-part-1/). Information covered includes tools for annotating texts, citing and managing citations, writing, data processing, time management, file management and product presentation. Some of these tools support relatively short-lived practices associated with coursework, such as writing papers or one-time formatting of references. Other tools focus on the formation of practices for producing scholarly knowledge typified by the later stages of the doctoral education such as writing a dissertation. These practices are likely to carry over into career-long professional post-degree scholarship, including developing personal libraries with records of provenance, conceptual and analytic organizational tools for data and publications, or monitoring publications in areas of interest within the research topics studied long-term by the scholar. As doctoral students begin more and more to participate in collaborative research, they begin using tools to support that collaborative use of information whether it be publications, data or works in progress. Olehnovica et al. (2013) recommend including digital fluency in doctoral studies, composed of ICT skills for participating in global networks, conducting and sharing research, managing research workflow and archiving information. These skills are needed to participate fully in scholarly communication and modern knowledge production in the academy. This article examines a cross section of the literature and makes recommendations based on the literature and data from previous studies. While the need to be information literate and have information problem-solving skills has always been a key learning need for junior scholars, the advance of technology toolsets and the increasing complexity of knowledge production increase this need. Doctoral students more than ever need support to develop robust skills in using technology to support their scholarly workflows, including digital literacy and, in particular, the intersection between digital literacy skills and information problem solving (IPS) skills in the context of scholarly knowledge production.

Scholarly digital literacy skills are often noted as a goal, but current definitions frequently overemphasize using knowledge and not producing it. These definitions do not always link digital literacy skills to information literacy skills or practices of scholarly knowledge production. For example, one organization defines digital literacy skills as the ability to use ICT tools to locate, evaluate, use, understand and create information and the ability to effectively perform tasks in a digital environment (Digital Literacy Definition and Resources, 2008), and a more recent definition from the United Kingdom's Joint Information Systems Committee (Jisc, 2015) calls digital literacy "the capabilities which fit someone for living, learning and working in a digital society.” Digital Literacy is closely intertwined with Information Literacy (also often called IPS skills). Bawden (2001) was the first to tie digital literacy and information literacy together, and although these literacies share dependencies on one another, they are not always associated together in recent frameworks.

Information literacy can be defined as the ability to define a problem, seek information, locate and access sources, use information, synthesize and evaluate information (Big6 Skills Overview, 2014). More current models, such as SCONUL (Society of College, National and University Libraries) (Pinfield et al., 2017) ACRL (Association of College and Research 
ILS

$120,3 / 4$

160

Libraries) Framework Literacy for Higher Education (2016), take information literacy a bit farther than previous models. The ACRL framework is as summarized by Secret et al. (2017, p.3) as:

Information Literacy Competency Standards for Higher Education to help ensure that students understand how knowledge is organized and know how to search for, critically evaluate, synthesize, and use reliable information ethically and in such a way that others can learn from this knowledge".

The framework most notably includes scholarly communication practices "Scholarship as Conversation. McClellan et al. (2017) demonstrate this in creating scholarly publishing information literacy training for graduate (and postgraduate students). The ACRL framework lays out the foundation skills for undergraduate and skills that doctoral students will have prior to entering a $\mathrm{PhD}$ program.

Much has been written about information literacy or IPS skills and the types of skills students need at the college level. However, research on these skills has focused almost exclusively on skills required of the student-cum-learner, not the student-cum-researcher. Especially in the North American context, undergraduates and non- $\mathrm{PhD}$ graduate students are not really involved in the knowledge production process of scholarly research. As a doctoral student, one is expected to conduct research, manage data, write a dissertation and produce scholarly works such as articles or conference papers. To do this, there is a certain level of research skill a doctoral student must obtain to be a successful researcher. A study conducted by Antonijević (2015, p. 38) categorizes the research process into the following areas: "collecting, finding, organizing, and analyzing research data and materials; writing up, annotating, and citing research data and materials; reflecting upon, sharing, communicating, and archiving research data and materials." However, Hicks and Sinkinson (2015, p. 537) point out that "few studies have examined digital literacy and the research process together to look holistically at what it will mean to be a digital scholar." Because there is limited published literature specifically on conceptualizing, measuring and supporting doctoral student IPS and digital literacy skills, we examine a cross-section of the literature available (primarily representing non-doctoral students) and attempt to frame its implications for nascent researchers (i.e. doctoral students or recent postdocs), with a particular focus on the potential role of libraries in supporting those skills. This paper examines current doctoral student practices and the types of skills needed to become a scholar in the twenty-first century.

\section{What do we expect from information literacy and digital literacy?}

Traditional models of information literacy are separate from, and complementary to, digital literacy, and align with the traditional role of libraries. For example, Eisenberg and Berkowitz (1990) see information literacy skills as defining the problem, identifying the information, locating and accessing the information, synthesizing what was found relevant and evaluating the results. The IPS model proposed by Eisenberg and Berkowitz, though conceived in the pre-internet age, contains foundational skills that are an important part of the process even with the shift from printed to digital information. However, current information practices (i.e. in final decenniums of the twentieth century) require a new skillset. Recent work by Walraven et al. (2008) developed an IPS model incorporating the internet as an information source.

Other recent models such as the ACRL Framework for Information Literacy for Higher Education (2016) address and foundational skills that may prepare doctoral students to conduct research. However, these models may not extend fully into the types of blended information and digital literacies required of scholars doing original research, such as 
doctoral students. For example, Exner (2014) suggests that the skills identified by ACRL will be obtained by the time the doctoral student begins the dissertation and that skills for a novice versus a researcher conducting original research are quite different:

\section{Role of libraries}

Analyzing the existing literature at higher levels, identifying and applying theory, mind-mapping and personal information management techniques to organize and support analytical work, and related advanced techniques are very different and very important to the support of original researchers (Exner, 2014, p. 463).

Exner concludes with advocating for empirical studies on scholarly researchers' behaviors and for librarians to pay close attention the information needs of graduate students, postdocs and early career researchers (2014).

Another complementary view on how information literacy is different for doctoral students is suggested by Koltay (2016), who notes that Vitae Researcher Development Framework (2018), is:

Slightly different from these documents [ACRL Framework for Information Literacy for Higher Education and SCONUL] because it demonstrates the role of IL in the researcher's' life through the researcher's' eyes (p. 96).

This framework contains the competencies a researcher should have and is mainly geared to the research and affiliated advisors, etc. Some of the areas in this model are part of the information literacy process or are areas covered by the libraries, but merely a model of the overall process.

The Researchers of Tomorrow study (Carpenter et al., 2012) includes an example case that may help illustrate some of these shortcomings. This particular doctoral student participant uses a wide variety of library-based and technology-mediated resources in his scholarly workflow (Carpenter et al., 2012, p. 30):

Alex has relied primarily on physical books in libraries for his research, followed by articles [...]. He finds it easy to get distracted by the many resources available, which he says may be interesting but aren't necessarily helpful to the research.

He finds it much easier to browse books on the shelf, particularly when looking for things in multiple languages [...]. He says that the online searching tools are not designed for this, and mean that students can't browse huge census volumes, so miss out on chance findings.

Alex does not consider himself very 'techie'. Although he uses social networking sites socially, he doesn't use them for research and wouldn't like to. He sees them as distracting, and is put off by the commercial element.

Alex regrets that he has never got to grips with bibliographic software such as EndNotes or RefWorks; he has done all his referencing the 'old-fashioned way'. He attended one short (one hour) and one long (three hour) session on RefWorks, but was unable to grasp how to practically incorporate it into his working methods. Often he found that training courses were somewhat baffling for people who do not have advanced computer skills.

He often found he had no time to keep up to date with recent research [...]. He hasn't used online tutorials or seminars, or found much use in videos on his topic.

Alex relies heavily on support from peers, and has found his supervisor's support and guidance invaluable $[\ldots]$ 


\section{ILS}

$120,3 / 4$

162

In this profile, we see a number of important elements of what was discussed above. First, Alex blends use of library-based information seeking and internet or socially based information seeking behaviors. His digital literacies and information literacies intersect, and he identifies many challenges that might benefit from training. These challenges occur both in information retrieval and in other aspects of the scholarly process (e.g. he also encounters challenges in his information management and knowledge management behaviors). Finally, it shows how Alex's needs and workflow are at least partially embedded in social collaboration and scholarly communication. He attempts to manage work alone with more socially interactive work and manage his time focused on scholarship vs other areas of his life (a challenge that grows as always-on technologies like twitter mediate scholarship). Other examples from the same study also help illustrate how these intersecting literacies and skills bump up against the boundaries of library-based work vs work via the open internet, and the ways in which all of the scholarly workflow dips in and out of collaboration, creating more challenges related to tools, literacies and practices that may not traditionally be addressed by libraries.

While many are trying to reformulate models for digital and information literacies appropriate to doctoral level researchers, and advocate identifying skills the doctoral students need or use, we advocate also taking a careful look at the shifting digital workflows of emerging scholars. These workflows quickly evolve based on new digital tools for scholarship. Many tools which are available for finding, accessing and curating in the digital age may impact the way IPS or information literacy should be taught. McBride (2011, p. 288) asks "Can you properly teach information literacy in the twenty-first century without considering the myriad of tools available to locate and create information?" These tools, along with the overabundance of information, present barriers for some. For instance, scholars may struggle with disconnects between proprietary or library-provided tools and open or freely available tools (Bruce et al., 2012; Favaro and Hoadley, 2014) especially with respect to the social aspects of its nature and use.

Another way doctoral information and digital literacy transcend prior models is due to the increasingly collaborative nature of work and knowledge construction. Monge and Frisicaro-Pawlowski (2014) note that information literacy falls short of twenty-first century workplace skills by not including social and collaborative learning, and by not encouraging "discipline-based information literacy to create and share information, and interact with web-based methods" (p. 71).

In part due to these pressures of modern scholarship, we see new models arising that combine in new ways what might previously be called information literacies and digital literacies. How do these skills factor into doctoral student research workflows? For scholars, Conceição (2013) identifies three important skills for success in the twenty-first century: information management (i.e. the ability to collect and manage information in multiple formats and disseminate it through various types of platforms), knowledge management: (i.e. communication, information transfer and collaboration), and publication management (i.e. the ability to understand the dissemination of scholarly work and new publishing modes). This parallels similar characterization in the Vitae RDF framework mentioned previously discussed. However, it is very cumbersome and extends outside of the library's role. It also does not go into detail on the types of skills (Molly and Snow, 2012). We believe in a simplified version with concrete research skills that can be applied to university library graduate programming. We propose a modified version of Conceição's framework that includes three necessary skills for doctoral students in the dissertation to have: information management, knowledge management and scholarly communication as essential skills for twenty-first century scholars extended with a fourth skill - Information Literacy. These are 
skills that are necessary for the research process and can be supported by librarians. Building on Conceição's work, we examine below essential skill-sets needed for doctoral students and early career researchers (i.e. students who have recently received their $\mathrm{PhD}$ and are working as post-docs and/or researchers): information literacy, information management, knowledge management and scholarly communications.

\section{What can we find out about these skills for doctoral students?}

Information problem solving or information literacy

There is limited research on doctoral-level information skill-sets (Fleming-May and Yuro, 2009; Patterson, 2009) with most major studies and projects primarily directed at undergraduate information literacy skill-sets (Bloom and Deyrup, 2015; Head, 2008; Head and Eisenberg, 2013; Leckie and Fullerton, 1999; Smith et al., 2013). But what is required of these groups differs greatly. Undergraduates are expected to have a minimum of:

Lower-order competencies, including skills such as using a variety of search systems to retrieve information in various formats, locating information within the library, and differentiating between primary and secondary sources (Maughan, 2001, p. 73).

Doctoral students, on the other hand, are expected to complete an exhaustive literature review (Boote and Beile, 2005) and typically, to do this alone, at least in the USA model of dissertation research. In this process, faculty tend to overestimate the research skills of their undergraduate students (Leckie, 1996) and have the misconception that these "digital natives" have somehow, often magically, acquired these knowledge sharing and knowledge building skills (Kirschner and van Merriënboer, 2013) which has been shown not to be the case (Margaryan et al., 2011). Also, faculty advisors expect doctoral students to have mastered the necessary research skills to conduct research (Rempel and Davidson, 2008), presumably based upon undergraduate courses on research design, research methodology and so forth. According to a study conducted by Baruzzi and Calcagno (2015), some students never receive library instruction at the undergraduate level and begin doctoral work without appropriate research skills for doctoral studies. Harris (2011) notes that doctoral students are not prepared to conduct true dissertation research when required to do so. Also, doctoral students are not always guaranteed formal training, as many university libraries tend to prioritize undergraduate research programs over graduate programs (Monroe-Gulick and Petr, 2012). Library literature reflects the need for research core-competencies for graduate students, i.e being able to find, locate and evaluate information (Blummer et al., 2010). Secret et al. (2017) note the need for collaboration between research methods faculty and librarians to ensure that graduate students have the necessary competencies.

Along with research skills, both internet and some technical skills are required as part of the research process. Collins and Veal (2005) found that an adult learner with a high level of library anxiety had a negative self-perception of his/her ability to access information using the internet for research. Studies demonstrate that doctoral students often are not aware of available library services and have limited interactions with librarians (Carpenter et al., 2012; Kayongo and Helm, 2010; Sadler and Bess, 2007). Access to library materials tends to occur through logging into the library databases from off-campus (Kayongo and Helm, 2009), and as such libraries and librarians are not part of the graduate student's research environment (Doucette and Fyfe, 2013). Doctoral students tend to rely more or even primarily on their academic networks, namely, their advisor and peers, for information and seek out the library only at a point of need (Carpenter et al., 2012). A study conducted by Ince et al. (2018) demonstrate the doctoral student's search process largely happens outside of the library (see Table I, excerpted from Ince et al., 2018, p. 246). 


\begin{tabular}{|c|c|c|c|c|}
\hline \multirow{2}{*}{$\begin{array}{l}\text { ILS } \\
120,3 / 4\end{array}$} & \multicolumn{2}{|c|}{ Search tools } & \multicolumn{2}{|c|}{ Alerting tools } \\
\hline & Tools & Users & Tools & Users \\
\hline \multirow{5}{*}{164} & Google Scholar & 8 & \multirow{13}{*}{$\begin{array}{l}\text { Google Scholar } \\
\text { Journal alerts } \\
\text { Twitter } \\
\text { Listservs } \\
\text { Mendeley } \\
\text { Google news } \\
\text { Follow people } \\
\text { ResearchGate } \\
\text { Email account for alerts } \\
\text { Conference reviewing } \\
\text { Research group sharing } \\
\text { Subscription to journal }\end{array}$} & 6 \\
\hline & WorldCat & 5 & & 4 \\
\hline & Rejects library search & 4 & & 3 \\
\hline & Library discovery & 3 & & 2 \\
\hline & Citation chasing & 3 & & 1 \\
\hline \multirow{9}{*}{$\begin{array}{l}\text { Table I. } \\
\text { Prevalence of tool use } \\
\text { for search and } \\
\text { alerting (Ince } \text { et al., } \\
\text { 2018, p. 246) }\end{array}$} & Zotero & 2 & & $\begin{array}{l}1 \\
1\end{array}$ \\
\hline & Twitter & 2 & & 1 \\
\hline & Email & 2 & & 1 \\
\hline & ERIC & 2 & & 1 \\
\hline & Facebook group(s) & 2 & & 1 \\
\hline & Google search & 1 & & 1 \\
\hline & Senate & 1 & & 1 \\
\hline & Pubmed & 1 & & \\
\hline & SciHub & 1 & & \\
\hline
\end{tabular}

Indeed, it is worth noting that while an undergraduate may directly perceive an information need (e.g. a class assignment which requires using library-based information the student does not possess), doctoral students often must notice and define their own information problems to be solved much more broadly (e.g. determining which literature(s) may be relevant to the definition of a research question, formulating a theoretical framework or selecting a research methodology). In other words, a doctoral student may actually be more likely to encounter an ill-defined information problem to solve. Thus, there are number of problems for doctoral students:

- overestimation of their IPS skills by their supervisors;

- actual lack of IPS skills;

- inadequate education and training for IPS;

- lack of awareness of library resources;

- ad hoc reliance on informal information networks/communities; and

- need to define and refine information problems to be solved.

Within the context of doctoral work, students need to develop powerful information literacy skills to help them as they encounter these ill-defined research-related information problems. However, even though students may have become adept at defining information needs and finding and evaluating information necessary to their scholarship, they still have to manage that information.

\section{Information management}

Information management is an important part of the research process. Where once a $\mathrm{PhD}$ student might have had stacks of tomes in a library carrel to manage as they wrote their dissertation longhand, current doctoral students have hard drives and email inboxes full of PDFs, data files, draft manuscripts and incomplete pointers to more information (Antonijević and Cahoy, 2014). There is formal training available for students at some universities. Oregon State University Library, for example, conducts graduate information literacy workshops for the literature review process, research tools to carry out the research process and establishing the role of the library in their continuing education (Rempel and Davidson, 2008). Rempel and 


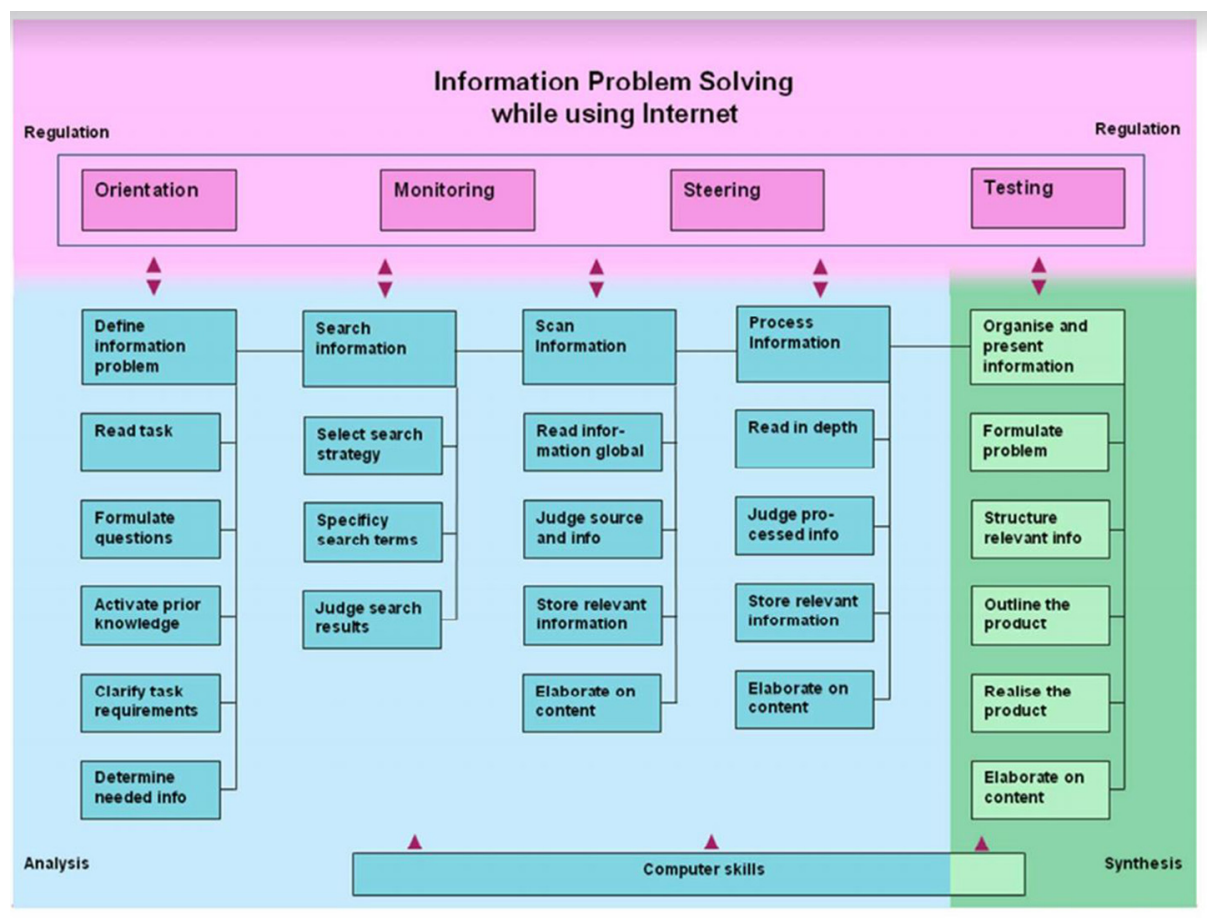

Role of libraries

165

Figure 1. Information problem solving while using internet (BrandGruwel, 2011)

Davidson (2008), for example, conducted a pre-assessment survey workshop (i.e. students approach to library research prior to library training) and found that the attendees had a strong interest in bibliographic management software. Gessner et al. (2011) report frustrations with managing information using citation tools, difficulties with eBook formats, and the need for an inclusive tool to support one's work. A further complication is that there is also a great number of useful tools (both library-provided and freely available on the internet), but that they are often not compatible with each other. Additionally, most students relied on advice from peers and advisors who are often not well versed in the possibilities and proper usage of the tools, rather than asking a librarian or technologist who is (Gessner et al., 2011). Studies of doctoral students' research behavior conducted by Carpenter et al. (2012) with support from the British Library and the Higher Education Funding Council for England (2012) had similar findings. Doctoral students only used technology that could readily fit within existing workflows, preferred using tools for new research alerts and relied largely on doctoral supervisors and peers for technology adoption. According to the study, among the students surveyed in Social Sciences, Arts and Humanities, approximately 90 per cent work alone. A social sciences student noted, "Outside of university I find myself using resources like RSS feeds and Twitter quite a lot to keep up to date with events and sources of information of possible use to my $\mathrm{PhD}$ project." (Carpenter et al., 2012, p. 36). One of the profile interviews for a social science student revealed the following:

Web-based resources: there is no guidance on how to manage web-based resources, which might disappear. How should researchers go about keeping a copy of them for referencing and referral purposes? (Carpenter et al., 2012, p. 54). 


\section{ILS}

$120,3 / 4$

Conrad et al. (2015) found that applications for managing citations, organizing documents, storing documents and conducting searches were the top tools used among graduate students. Additionally, the need for cloud storage and collaborative research software (Conrad et al. (2015)). Secker and Macrae-Gibson (2011) recommend a six-week course for $\mathrm{PhD}$ candidates covering traditional skills for library databases searching, using freely available search engines, locating newspapers, conference papers and theses, using alerting services and managing citations. Findings from students participating in the course showed an increase in confidence in using this skill-set (Secker and Macrae-Gibson, 2011). Information management is an important part of the research process and information management skills are needed to sift through large amounts of information.

\section{Knowledge management}

Knowledge management $(\mathrm{KM})$ is the process of capturing, curating and sharing information (Dalkir and Liebowitz, 2011). Library Science literature reflects the use of KM tools and practices internal to the library, but not within the research process. This is very important for researchers, and doctoral students indicate unmet needs to learn these skills. A 2013 Association of Research Libraries report cites KM as one the top skills subjects librarians advise on while on the Reference Desk (Jaguszewski and Williams, 2013). Curating information (i.e. the on-going management of information) is perhaps the hardest skill to master, as doctoral students tend to compile an abundance of information for the literature review but have difficulties discarding and/or parking/archiving information that may be momentarily irrelevant but which may be useful at later date, or creating organizational systems appropriate to the knowledge production goals they are pursuing. Ultimately, professional expert scholars may have and use a comprehensive knowledge base that includes a variety of types of information (e.g. published papers, data, draft manuscripts, reference materials), but this requires a career-long commitment to building systems that allow this knowledge base to effectively evolve, and often also involves migrating those systems across ever-changing technology platforms.

While the challenge of managing literature is an early and obvious one in a doctoral student's career, an additional important aspect of KM is data literacy and data management. These are important skills for doctoral students to understand as part of the process to becoming a scholar. Many granting agencies require data management plans and open access to data, and scholarly publication venues are increasingly requesting 'audit trails' such as archiving copies of the statistical scripts used to reduce or analyze data as well as the data itself. A study of research data management skills of graduate students and post-doctoral researchers in the sciences conducted by Wiley and Kerby (2018) indicated they had no experience writing a data management plan or following a data management plan and received no formal training nor were they aware that data management and preservation training were available. Interestingly, the students noted the main issues are organization of research workflow including how to store and disseminate data (Wiley and Kerby, 2018). Doucette and Fyfe (2013) found social science students indicating higher understanding of research data management practices than science students though these seem to be self-taught. Another finding indicated that very few students had discussed research data management with a librarian, but instead sought guidance from faculty members and other graduate students (Doucette and Fyfe, 2013). Recommendations include future studies for library training for graduate students in Research Data Literacy for best practices. Archiving is another key area. Antonijevic (2015) found that researchers backup to email, hard drives and cloud-based services. Being able to secure and preserve research is critical to the research process and some cases may be a requirement of funding agencies. 
KM practices, such as data management skills, contribute to scholarly communications, and have a direct impact on the workflows doctoral students need to create or adopt. Like IPS skills, KM skills are not generally well taught or supported and form a significant challenge to doctoral students.

Thus, we see students need help locating and managing information in their scholarship, including information literacy skills, information management skills and knowledge management skills. But perhaps the most rapidly changing aspect of the life of the modern scholar is in communicating with others, before, during and after doing research.

\section{Role of libraries}

\section{Scholarly communication}

Another important aspect of the research workflow for doctoral students is the scholarly communication process. Scholarly communication is defined as:

The system through which research and other scholarly writings are created, evaluated for quality, disseminated to the scholarly community, and preserved for future use. The system includes both formal means of communication, such as publication in peer-reviewed journals, and informal channels, such as electronic listservs (ACRL, 2003; Principles and Strategies for the Reform of Scholarly Communication 1, para 1).

Doctoral students should have an understanding of the scholarly communication process including publishing articles and books, presenting at scientific conferences, contributing to conference proceedings and knowing how information is disseminated in general (including the valorization of research results for society at large through the press, popular and/or trade journals, blogs, social media and so forth). However, doctoral students tend not to have an understanding of the scholarly communication process, and therefore are not familiar with many of the available dissemination channels, not the least of which is the online dissemination of their research (Olehnovica et al., 2013). It should be noted that scholarly communication, like many other forms of communication in the twenty-first century, is changing rapidly. Differing norms are held by different disciplines, but moreover by different academic "generations." This can lead to confusion about acceptability of different dissemination channels and practices, not to mention a need to constantly examine optimal strategies for scholarly dissemination. In this context, understanding some of the important foundations on which scholarly publishing rests becomes an important touchstone for doctoral training. These foundations include understanding issues such as copyright and fair use; evolving platforms through which scholarship is disseminated (including not only traditional publications and conferences but also social media and non-traditional Internet based publication venues); and how to integrate these new developments into their own workflows (Gregory and Saheli Singh, 2018).

To this end, an understanding of open access coupled with copyright knowledge is a very important skill for information dissemination. Rempel (2010) notes that open access and scholarly communications can also help graduate students expand their skills. Following this rapidly changing area includes the need to better understand issues such as depositing information with subject, data and institutional repositories and checking and understanding publisher permissions by using resources such as SherpaRomeo and SherpaJuliet for research funding open access policies. Other places that tend be popular places for scholars to deposit or share information include academic networking sites such as ResearchGate ${ }^{\circledR}$ and academia.edu ${ }^{\circledR}$.

In addition to the more "traditional" knowledge and skills, social media (e.g. Facebook ${ }^{\circledR}$, Twitter $^{\circledR}$, LinkedIn ${ }^{\circledR}$ and so forth) are also playing an increasingly important role in the research workflow. A study from CIBER, Center for Publishing, University College London 
ILS

$120,3 / 4$

\section{8}

(Rowlands et al., 2011) found that 84 per cent of social scientists use social media tools in their research workflow. In that study, they identified seven stages of social media and the research workflow, namely, "identifying research opportunities, finding collaborators, securing support, reviewing the literature, collecting research data, analyzing research data, disseminating findings, and finally managing the research process" (p. 190). Social media also play important role with respect to staying up to date with one's information, building a network and/or sharing information or scholarly works. Millan and Bromage (2011) recommend that doctoral students establish networks to engage in global scholarly activities for research, sharing information and reviewing other works. Rowlands et al. (2011) found that social media have an impact on all points of the research lifecycle. Nicholas et al. (2017) noted ResearchGate ${ }^{\circledR}$ as the most popular platform followed by LinkedIn and Twitter for the following uses: "Finding information, communicating information, sharing, building a digital profile/presence, obtaining PDFs, and engaging in outreach activities" (p. 8). Through open access, scholars can disseminate their work through their own online presence or repositories (if allowed by copyright agreement).

\section{Conclusions}

In this paper, we have begun to examine some of the needs of doctoral students, especially those conducting doctoral research, in supporting a workflow of scholarship. There are four important skill-sets for doctoral students are: information literacy, information management, knowledge management and understanding the lifecycle of scholarly communication.

When doctoral students need to construct such workflows, it poses educational challenges to universities, including how to foster the right kinds of skills and literacies, which may be quite distinct from those supported for non-research-intensive students such as undergraduates. In addition, doctoral students specifically (and research scholars more generally) face challenges in integrating these skills into the day-to-day tools, practices and workflows that help them turn their labor into knowledge production for the scholarly community.

Several frameworks help us understand what these skills and workflows rely upon. Information literacy frameworks, and IPS especially, help us conceptualize how scholars locate and use information. Knowledge management frameworks help us conceptualize how scholars may curate and construct knowledge bases for themselves for current and future use. Frameworks for scholarly publishing help us conceptualize how scholars adapt to a rapidly changing publishing environment and to integrate tools like social media into their work alongside more traditional forms of publishing and dissemination. These frameworks help us theorize what kinds of knowledge we should support in doctoral students, both through training and/or instruction, and through supportive tools and/or practices. More work is needed to empirically determine the following:

- What skills doctoral students in different fields and different contexts actually possess in terms of these new literacies and skills?

- What are current and future best practices to support development of these new literacies and skills?

We strongly believe that not only is research needed on this topic but also that increasingly universities, libraries and the community of expert research scholars will need to support the next generation of scholars to develop these skills and practices that can greatly enhance the effectiveness of students learning to become researchers. 
Supporting emerging scholars in learning these skills will require careful consideration of the complementary roles of libraries, academic coursework, research supervisors and other activities in the field such as training materials or policy documents from professional organizations. Because research supervisors' own practices may not fully embrace the newest shifts in the knowledge production and dissemination landscape, libraries play a critical role. Librarians are often the only professionals in this ecosystem whose role requires currency not only in information practices but also in shaping and providing access to the technical tools scholars use. As scholarship moves away from institutionally provided and supported technology tools to freely available tools on the open Web such as Twitter or Google Scholar, this further stretches the role of librarians and increases the complexity of supporting and training young scholars. We hope that discussion and coordination among disciplinary experts such as dissertation advisors or leaders in scholarly disciplines, librarians and technology providers could allow the evolution of better ensembles of tools, training and human resources for the needs of not only emerging scholars but also established scholars. Given the rapidly changing landscape, all stakeholders in this system are likely to need some kind of continual professional development, and the chaotic state of training and tools hampers meeting this need. Our proposed four-part framework may be useful in identifying where people can come together to think about how the scholars of tomorrow learn to use the resources available today as they begin fully participating in the practices of scholarly knowledge production.

\section{References}

ACRL Framework for Information Literacy for Higher Education (2016), available at: www.ala.org/ acrl/standards/ilframework (accessed 12 August 2018).

ACRL Scholarly Communications Committee (2003), "Principles and strategies for the reform of scholarly communication 1", available at: www.ala.org/acrl/publications/whitepapers/ principlesstrategies (accessed 16 April 2017).

Antonijević, S. (2015), “Amongst digital humanists: an ethnographic study of digital knowledge production”, Palgrave Macmillan, New York, NY.

Antonijević, S. and Cahoy, E.S. (2014), "Personal library curation: an ethnographic study of scholars' information practices", Portal: Libraries and the Academy, Vol. 14 No. 2, pp. 287-306.

Baruzzi, A. and Calcagno, T. (2015), "Academic librarians and graduate students: an exploratory study", Portal: Libraries and the Academy, Vol. 15 No. 3, pp. 393-407.

Bawden, D. (2001), "Information and digital literacies: a review of concepts", Journal of Documentation, Vol. 57 No. 2, pp. 218-259.

Bloom, B. and Deyrup, M.M. (2015), "The SHU research logs: student online search behaviors transscripted", The Journal of Academic Librarianship, Vol. 41 No. 5, pp. 593-601.

Blummer, B., Kenton, J.M. and Song, L. (2010), "The design and assessment of a proposed library training unit for education graduate students", Internet Reference Services Quarterly, Vol. 15 No. 4, pp. 227-242, doi: http://dx. doi.org/10.1080/10875301.2010.526491

Boote, D.N. and Beile, P. (2005), "Scholars before researchers: on the centrality of the dissertation literature review in research preparation”, Educational Researcher, Vol. 34 No. 6, pp. 3-15.

Brand-Gruwel, S. (2011), "10 years of research on information problem solving, ", Centre of Learning Sciences and Technologies, Heerlen, available at: http://dspace.ou.nl/handle/1820/3221 (accessed 19 April 2017).

Bruce, C., Hughes, H. and Somerville, M.M. (2012), "Supporting informed learners in the twenty-first century", Library Trends, Vol. 60 No. 3, pp. 522-545, doi: http://dx. doi.org/10.1353/lib.2012.0009 


\section{ILS $120,3 / 4$}

Carpenter, J., Wetheridge, L. and Tanner, S. (2012), "Finding and using research resources. researchers of tomorrow: the research behaviour of generation y doctoral students", (British Library, London:), available at: www.webarchive.org.uk/wayback/archive/20140614205429/http://www.jisc.ac.uk/ media/documents/publications/reports/2012/Researchers-of-Tomorrow.pdf (accessed 9 July 2018).

Collins, K.M. and Veal, R.E. (2005), "Off-campus adult learners' levels of library anxiety as a predictor of attitudes toward the internet", Library and Information Science Research, Vol. 26 No. 1, pp. 5-14. doi:, doi: 10.1016/j.lisr.2003.11.002.

Conceição, S.C. (2013), "Skills needed to survive and thrive as a scholar in the 21st century information, knowledge, and publication management", Adult Learning, Vol. 24 No. 4, pp. 175-178, doi:10.1177/1045159513499552.

Conrad, L.Y., Leonard, E. and Somerville, M.M. (2015), "New pathways in scholarly discovery: understanding the next generation of researcher tools", In Association of College and Research Libraries Conference, pp. 25-28.

Dalkir, K. and Liebowitz, J. (2011), "Knowledge Management in Theory and Practice" (2), The MIT Press, Cambridge.

Doucette, L. and Fyfe, B. (2013), "Drowning in research data: addressing data management literacy of graduate students", In Imagine, Innovate, Inspire: The Proceedings of the ACRL 2013 Conference in Indianapolis, IN, pp. 165-171.

Eisenberg, M. and Berkowitz, R. (1990), "Information Problem-Solving: The Big Six Approach to Library and Information Skills Instruction", Ablex, Norwood, NJ.

Exner, N. (2014), "Research information literacy: addressing original researchers' needs", The Journal of Academic Librarianship, Vol. 40 No. 5, pp. 460-466.

Favaro, S. and Hoadley, C. (2014), "The changing role of digital tools and academic libraries in scholarly workflows: a review”, Nordic Journal of Information Literacy in Higher Education, Vol. 6 No. 1, pp. 23-38.

Fleming-May, R. and Yuro, L. (2009), "From student to scholar: the academic library and social sciences PhD students' transformation", Portal: Libraries and the Academy, Vol. 9 No. 2, pp. 199-221, doi: 10.1353/pla.0.0040.

Gessner, G.C., Jaggars, D.E., Rutner, J.A. and Tancheva, K. (2011), "Supporting humanities doctoral student success: a collaborative project between cornell university library and columbia university libraries", available at: http://academiccommons.columbia.edu/catalog/ac:140506 (accessed 19 April 2017).

Harris, C.S. (2011), "The case for partnering doctoral students with librarians: a synthesis of the literatures", Library Review, Vol. 60 No. 7, pp. 599-620. DOI: http://dx.doi.org/10.1108/ 00242531111153614 .

Head, A.J. (2008), "Information literacy from the trenches: How do humanities and social science majors conduct academic research?", College and Research Libraries, Vol. 69 No. 5, pp. 427-446.

Hicks, A. and Sinkinson, C. (2015), "Examining mendeley: designing learning opportunities for digital scholarship", Portal: Libraries and the Academy, Vol. 15 No. 3, pp. 531-549.

Hoadley, C. (2011), "The lifecycle of knowledge as seen from the learning sciences", Position statement shared at the ReX2: The Re:Enlightenment Exchange, available at: www.reenlightenment.org/ exchangelondon (accessed 19 April 2017).

Ince, S.F., Hoadley, C. and Kirschner, P.A. (2018), "A study of search practices in doctoral student scholarly workflows", In Proceedings of the 2018 Conference on Human Information Interaction and Retrieval pp. 245-248. ACM, doi: https://dl.acm.org/citation.cfm?doid=3176349.3176877

Jaguszewski, J. and Williams, K. (2013), "New roles for new times: transforming liaison roles in research libraries", Association of Research Libraries.

Kayongo, J. and Helm, C. (2010), "Graduate students and the library", Reference and User Services Quarterly, Vol. 49 No. 4, pp. 341-349. 
Kirschner, P.A. and van Merriënboer, JJ. (2013), "Do learners really know best? urban legends in education”, Educational Psychologist, Vol. 48 No. 3, pp. 169-183.

Koltay, T. (2016), "Are you ready? tasks and roles for academic libraries in supporting research 2.0", New Library World, Vol. 117 Nos 1/2, pp. 94-104, doi: https://doi. org/10.1108/NLW-09-2015-0062

Gregory, K. and saheli singh, s. (2018), "Anger in academic twitter: sharing, caring, and getting mad online", tripleC: Communication, Capitalism and Critique. Open Access Journal for a Global Sustainable Information Society, Vol. 16 No. 1, pp. 176-193.

Leckie, G.J. (1996), "Desperately seeking citations: uncovering faculty assumptions about the undergraduate research process", The Journal of Academic Librarianship, Vol. 22 No. 3, pp. 201-208.

Leckie, G.J. and Fullerton, A. (1999), "Information literacy in science and engineering undergraduate education: faculty attitudes and pedagogical practices", College and Research Libraries, Vol. 60 No. 1, pp. 9-29.

McBride, M.F. (2011), "Reconsidering information literacy in the 21st century: the redesign of an information literacy class", Journal of Educational Technology Systems, Vol. 40 No. 3, pp. 287-300. doi: 10.2190/ET.40.3.e.

McClellan, S., Detmering, R., Martinez, G. and Johnson, A.M. (2017), "Raising the library's impact factor: a case study in scholarly publishing literacy for graduate students", Portal: Libraries and the Academy, Vol. 17 No. 3, pp. 543-568.

Margaryan, A., Littlejohn, A. and Vojt, G. (2011), "Are digital natives a myth or reality? university students' use of digital technologies”, Computers and Education, Vol. 56 No. 2, pp. 429-440. DOI: 10.1016/j.compedu.2010.09.004.

Maughan, P.D. (2001), "Assessing information literacy among undergraduates: a discussion of the literature and the university of California-Berkeley Assessmentexperience", College and Research Libraries News, Vol. 71 No. 2, pp. 71-85.

Millan, N. and Bromage, A. (2011), "An initial approach to the integration of web 2.0 technologies in the research environment”, Interactive Technology and Smart Education, Vol. 8 No. 3, pp. 148-160.

Monge, R. and Frisicaro-Pawlowski, E. (2014), "Redefining information literacy to prepare students for the 21st century workforce", Innovative Higher Education, Vol. 39 No. 1, pp. 59-73. DOI: 10.1007/ s10755-013-9260-5.

Monroe-Gulick, A. and Petr, J. (2012), "Incoming graduate students in the social sciences: how much do they really know about library research?", Portal: Libraries and the Academy, Vol. 12 No. 3, pp. 315-335, available at: http://dx. doi.org/10.1353/pla.2012.0032

Nicholas, D., Watkinson, A., Boukacem-Zeghmouri, C., Rodríguez-Bravo, B., Xu, J., Abrizah, A., Ś wigon, M. and Herman, E. (2017), "Early career researchers: scholarly behaviour and the prospect of change", Learned Publishing, Vol. 30 No. 2, pp. 157-166. doi:10.1002/leap.1098.

Olehnovica, E., Kravale-Paulina, M. and Bolgzda, I. (2013), "Doctoral students' competences of using online resources for research purposes in network society", Procedia-Social and Behavioral Sciences, Vol. 106, pp. 896-900. doi: 10.1016/j.sbspro.2013.12.102.

Patterson, A. (2009), "A needs analysis for information literacy provision for research: a case study in university college Dublin”, Journal of Information Literacy, Vol. 3 No. 1, pp. 5-18, available at: http://dx. doi.org/10.11645/3.1.210

Pinfield, S., Cox, A. and Rutter, S. (2017), Mapping the future of academic libraries: a report for SCONUL.

Rempel, H.G. (2010), "A longitudinal assessment of graduate student research behavior and the impact of attending a library literature review workshop", College and Research Libraries, Vol. 71 No. 6, pp. 532-547. doi: 10.5860/crl-79.

Rempel, H.G. and Davidson, J. (2008), "Providing information literacy instruction to graduate students through literature review workshops", Issues in Science and Technology Librarianship, Vol. 53 No. 2, doi: $10.5860 /$ crl-79. 


\section{ILS}

$120,3 / 4$

Rowlands, I., Nicholas, D., Russell, B., Canty, N. and Watkinson, A. (2011), "Social media use in the research workflow", Learned Publishing, Vol. 24 No. 3, pp. 183-195. doi: 10.1087/20110306.

Secker, J. and Macrae-Gibson, R. (2011), "Evaluating MI512: an information literacy course for PhD students", Library Review, Vol. 60 No. 2, pp. 96-107. DOI: 10.1108/00242531111113050.

Secret, M., Bryant, N.L. and Cummings, C.R. (2017), "Teaching an interdisciplinary Graduate-Level methods course in an Openly-Networked connected learning environment: a glass Half-Full", Journal of Educators Online, Vol. 14 No. 2, p.n2.

Smith, J.K., Given, L.M., Julien, H., Ouellette, D. and DeLong, K. (2013), "Information literacy proficiency: assessing the gap in high school students' readiness for undergraduate academic work", Library and Information Science Research, Vol. 35 No. 2, pp. 88-96.

Walraven, A., Brand-Gruwel, S. and Boshuizen, H.P.A. (2008), "Information-problem solving: a review of problems students encounter and instructional solutions", Computers in Human Behavior, Vol. 24 No. 3, pp. 623-648. doi: 10.1016/j.chb.2007.01.030.

Wiley, C.A. and Kerby, E.E. (2018), "Managing Research Data: Graduate Student and Postdoctoral Researcher Perspectives", Issues in Science and Technology Librarianship.

\section{Further reading}

The Big6 (2017), "Big6 skills overview”, available at: http://big6.com/pages/about/big6-skills-overview. php

Brand-Gruwel, S., Wopereis, I. and Vermetten, Y. (2005), "Information problem solving by experts and novices: analysis of a complex cognitive skill”, Computers in Human Behavior, Vol. 21 No. 3, pp. 487-508.

Bray, R. and Boon, S. (2011), "Towards a framework for research career development: an evaluation of the UK's vitae researcher development framework", International Journal for Researcher Development, Vol. 2 No. 2, pp. 99-116.

Head, A.J. and Eisenberg, M.B. (2011), "How college students use the web to conduct everyday life research", First Monday, Vol. 16 No. 4.

Ringland, K. (2016), "Graduate student workflow", Part 1, available at: http://kateringland.com/gradstudent-workflow-part-1/ (accessed 11 May 2018).

Sadler, E. and Given, L.M. (2007), "Affordance theory: a framework for graduate students' information behavior", Journal of Documentation, Vol. 63 No. 1, pp. 115-141.

University of Illinois at Urbana-Champaign Library (2008), "Digital literacy definition and resources", Retrieved 28 October 2016, available at: www.library.illinois.edu/diglit/definition.html (accessed 17 April 2017).

Vitae realising the potential of researchers (2018), "About the vitae researcher development framework", available at: www.vitae.ac.uk/researchers-professional-development/about-thevitae-researcher-development-framework (accessed 8 August 2018).

\section{Corresponding author}

Sharon Ince can be contacted at: sharon.favaro@nyu.edu

For instructions on how to order reprints of this article, please visit our website:

www.emeraldgrouppublishing.com/licensing/reprints.htm

Or contact us for further details: permissions@emeraldinsight.com 